\title{
Enhancing Reading Comprehension of Junior High School Students Through Scaffolding Instruction
}

\author{
Lasim Muzammil* \\ English Education Study Program \\ Universitas PGRI Kanjuruhan Malang \\ Malang, Indonesia \\ *muzammil_lasim@unikama.ac.id
}

\author{
Saifullah \\ Master of English Education Study Program \\ Universitas PGRI Kanjuruhan Malang \\ Malang, Indonesia \\ kangipulmg@gmail.com
}

\begin{abstract}
Scaffolding, as one of the structured-teaching learning strategies on language skills, has been developed worldwide including in Indonesian context. This paper investigates the effect of using scaffolding to enhance reading comprehension of ninth-grade students in SMP Negeri 04 Batu, East Java, Indonesia. The present study employs a quantitative research design which involves 30 participants (i.e. 12 males and 18 female), and their average ages are 15 years old. The instruments used in the study are pre-test and post-test besides questionnaire. The tests are done before and after using the scaffolding strategy and the questionnaire are used to identify the students' perception and feeling after the implementation of the strategy. Data analysis are carried out using paired-samples t-test and the questionnaire (5-Likert scales) are analyzed descriptively. The results of the study show a significant difference between before and after using the scaffolding strategy. It indicates that the scaffolding strategy practiced by the students could build their reading comprehension skills by means of steps by steps activity. Besides, the students feel more comfortable and eager to read more authentic reading material on account of this strategy. Therefore, it is recommended for teachers and syllabus designers to include scaffolding instruction to enhance the students reading comprehension.
\end{abstract}

Keywords—scaffolding, reading comprehension, instructional strategy, classroom activity

\section{INTRODUCTION}

Reading comprehension is an activity to obtain information from reading texts that involves a complex process to get meaning in the text being read. When someone reads the text, the person must first understand the words in the reading which can be interpreted for later information. Yet, difficulties in understanding the meaning of a sentence, paragraph, or text as a whole are inevitable and therefore it requires a certain strategy to achieve this purpose. One of the strategies to ensure that learners understand the texts and to overcome their problems of reading comprehension as well is a scaffolding instruction strategy. It is a process that enables child or novice to solve a problem, carry out a task or achieve a goal which would be beyond his unassisted efforts (Wood et al., 1976). In other word, scaffolding is a way to support children's learning of language moving from simple to more complicated one in learning a new skill by building on skills they already have.

Teaching and learning using scaffolding give many advantages in facilitating the teaching and learning process, not only for applying in elementary school but also for Junior High School and University. Wood et al. [1] argues that the teacher or tutor greatly influences how the development of students' abilities, the proper interaction between students and teachers can provide a significant increase in student learning outcomes especially in terms of foreign language learning. Interaction between teacher and student through scaffolding can also overcome student obstacles and difficulties. In a study conducted by Wood et al. [1] students consisting of adults received appropriate support from their tutors so that they showed better learning outcomes. According to Reiser [2] Scaffolding involves the teacher's efforts to help students solve problems that students cannot overcome. Learning activities in the scaffolding method are not passive learning activities but rather involve many active activities related to behavior tutorials [3]. In line with this, Suherdi [4] argues that in the scaffolding method, there are instructions given to students. The teacher provides quite complex problems that cannot be worked on by the students themselves and requires cooperation with their friends; in this case, if students continue to find difficulties, the teacher assists in the form of motivation, guidance, and example. However, research design results for the observational studies recently predominate with fewer experimental, mixed methods, and correlational studies [5].

Studying and applying scaffolding has been done by previous researchers and teachers affecting different findings. First, A study conducted by Safadi and Rababah [6] entitled "The effect of scaffolding instruction on reading comprehension skills", showed that scaffolding instruction is effective to improve students' ability to read comprehension. Their study aimed to determine the effect of scaffolding on the 11th-grade students in Jordan. Based on the results of the study, it is known that this scaffolding method, if executed optimally and appropriately, can provide significant results on improving students' reading skills [6]. Second, research conducted by Salem [7] entitled "Scaffolding Reading Comprehension Skills." Salem's research aims to investigate 
the effect of scaffolding on students' reading comprehension abilities. In contrast to previous studies, Salem's study is a descriptive qualitative study. The choice of method is based on the reason that the type of descriptive research is following the formulation of the problem to be answered. The results showed that often teachers could not determine what method was appropriate to improve their students' reading skills. The teacher is not fully aware of the benefits of implementing the scaffolding method on students' reading abilities. Third, a quasi-experimental study which developed a digital learning environment to scaffold students' expository text reading revealed that the high-multimodal scaffolding text significantly boosted science reading comprehension for low-skilled comprehends [8]. It is also in line with ter Beek et al. [9] found no differences between conditions regarding students' selfregulated learning or motivation, but students' awareness of problem-solving reading strategies significantly increased in the experimental condition. Furthermore, the study of Sholeh et al. [10] on Scaffolded Voluntary Reading (SVR) showed that the SVR not only significantly influenced students' achievement in EFL reading comprehension but promoted the students' self-selected reading, independent reading, and student-centered learning as well. Fourth, Dewi and Muzammil [11] research deal with one of the component on scaffolding strategy, using direct metacognitive strategy, revealed that most students had a more positive attitude concerning reading ability after they were trained with direct strategies. The results also revealed that the strategies made them better readers. Fifth, Instructional practices for scaffolding emergent bilinguals' comprehension of informational science texts also used qualitative data analysis found that explicit attention to language, and engagement with multimodal representations of core concepts can create multiple opportunities for students' analysis of both the language and meaning in informational science texts [12].

To date, studies concerning scaffolding instruction on reading comprehension resulted with different outcome and most researchers conducted the study using qualitative method with survey design. The observational studies predominate with fewer experimental, mixed methods, and correlational studies [5]. The present study investigates the effect of scaffolding instruction on reading comprehension for junior high school and therefore it is still necessary to be carried out in order to enlarge the nuances of the research field of quantitative method.

\section{A. Research Questions:}

- Does the use of scaffolding instruction strategy enhance the junior high school students' reading comprehension?

- What are the junior high school students' perception of using scaffolding instruction strategy on reading comprehension?

\section{B. Hypothesis:}

- Ho: The use of scaffolding instruction strategy does not enhance the junior high school students' reading comprehension.
- Ha: The use of scaffolding instruction strategy enhances the junior high school students' reading comprehension.

\section{METHODS}

The research was conducted in SMP Negeri 04 Batu, East Java, Indonesia. It is a quantitative approach using pre experimental design which aims to explain the participants accurately while using Scaffolding in the teaching and learning process. This quantitative research method is used to investigate the effectiveness of using scaffolding technique in teaching reading text. The research participants are 32 students at ninth grade of SMP Negeri 04 Batu with 12 males and 20 females. Their average ages are 15 years old. The instruments of this research are tests and questionnaire. Pre-test was conducted to check the condition of the learners before treatment is given. Post-test is conducted after the treatment was done. The result of the pre-test was compared to the result of post-test in order to check the effectiveness of the strategy used in the present study. Besides, questionnaire was distributed to learners after they have experience of learning reading using scaffolding strategy. It is aimed at the students' perception, attitude, and feeling as well.

Data were collected before and after the treatments. The results of the test in term of scores were analyzed using paired sample t-test since the participants are the same subject measured twice before and after treatment. The score from pretest was compared to the score of post-test which aims to investigate whether the difference is significant or not. The reading comprehension test consisted of 25 question and answer items containing five (5) multiple choice comprehension items, ten (10) yes/no question items, and ten (10) Wh-question items which was then converted into 0 to 100 band score by dividing the total score from maximum score and multiplied by 100 . Furthermore, data from questionnaire were collected using Google form and analyzed descriptively. There were 12 statements written questionnaire to provide the learners' perception and attitude after using scaffolding instruction (see TABLE III) for the result of questionnaire section.

The researchers used easy English reading materials in the form of short story which were suitable for beginner level. The choice of these materials were on account of some considerations: (1) it is a graded reader material which suitable for scaffolding subject matter instruction, (2) it is easy to find out since it is provided online at http://www.rong-chang.com, (3) the link provides both text and audio which benefit learners not only for reading but listening as well, (4) the text are short enough to make the practice reading faster, and (5) it's also provided with pronunciation, vocabulary, and grammar point. The materials are free of charge for learners. The following topics covered for the purpose of doing the present research were: (1) Birthday Celebration, (2) Parental Punishment, (3) Sharing is Caring, (4) The School Bully, (5) Junk Food, (6) Writing a Story, (7) Shopping for a Backpack, (8) Summer Reading Program, (9) Online Stranger, and (10) He Hates Poetry. Meanwhile, the treatment condition using scaffolding instruction was explained and seen in Table 1 as follows. 
TABLE I. The TrEatMent CONDITION USING SCAFFolding INSTRUCTION

\begin{tabular}{|c|c|c|c|}
\hline $\begin{array}{c}\text { Meet } \\
\text { ings }\end{array}$ & Activities & Researcher & Learners \\
\hline 1 & $\begin{array}{l}\text { Preparing and } \\
\text { administering } \\
\text { pre-test }\end{array}$ & $\begin{array}{l}\text { Give the test of } \\
\text { reading text }\end{array}$ & Do the pre-test \\
\hline 2 & $\begin{array}{l}\text { Giving } \\
\text { treatment of } \\
\text { reading }\end{array}$ & $\begin{array}{l}\text { The researcher } \\
\text { gave narrative text } \\
\text { was aimed to } \\
\text { identify the } \\
\text { generic structure } \\
\text { and language } \\
\text { feature of the text } \\
\text { to identify the } \\
\text { words; verb, noun, } \\
\text { and adjective are } \\
\text { probably often } \\
\text { used for narrative } \\
\text { text. }\end{array}$ & $\begin{array}{l}\text { The students read the } \\
\text { text was given by the } \\
\text { researcher. } \\
\text { The students work in } \\
\text { a pair to find the point } \\
\text { of them. }\end{array}$ \\
\hline $3-11$ & $\begin{array}{l}\text { Giving } \\
\text { treatment } \\
\text { reading }\end{array}$ & $\begin{array}{l}\text { The researcher } \\
\text { begins by } \\
\text { conveying the } \\
\text { learning } \\
\text { objectives, the } \\
\text { teacher } \\
\text { communicating } \\
\text { the learning } \\
\text { objectives in } \\
\text { general and then } \\
\text { conveying the } \\
\text { specific objectives } \\
\text { of reading. } \\
\text { The researcher } \\
\text { gave students text } \\
\text { and form of } \\
\text { Scaffolding. The } \\
\text { students worked } \\
\text { individually in } \\
\text { reading the text } \\
\text { based on } \\
\text { Scaffolding } \\
\text { guidance. } \\
\text { The researcher } \\
\text { discussed with the } \\
\text { students about the } \\
\text { topic of reading } \\
\text { text. } \\
\text { The researcher } \\
\text { give reflection of } \\
\text { the teaching and } \\
\text { learning activities. }\end{array}$ & $\begin{array}{l}\text { The students pay } \\
\text { attention to the } \\
\text { researcher instruction. } \\
\text { The student read the } \\
\text { text using Scaffolding } \\
\text { instruction. } \\
\text { Students predict what } \\
\text { will be read. } \\
\text { their conclusion and } \\
\text { understanding about } \\
\text { the text. }\end{array}$ \\
\hline 12 & $\begin{array}{l}\text { Administering } \\
\text { post-test }\end{array}$ & Give the post-test & Do the test \\
\hline
\end{tabular}

In the first meeting, the researchers gave pre-test and continued to the second meeting by giving narrative text aimed to identify the generic structure and language feature of the text to identify the words; verb, noun, and adjective are probably often used for narrative text, the students work in a pair to find the point of them. In the third up to the eleventh meeting, the researchers gave students text and form of Scaffolding. The students worked individually in reading the text based on Scaffolding guidance. Finally, in the twelfth meting, the students got post-test to find out their success of applying Scaffolding instruction.

\section{RESULTS AND DISCUSSION}

The result of the present study was divided into two parts. Part one elucidated the result of pre-test and post-test, and part two explained the results of questionnaire. In the first part, the result of pre-test and post-test was shown based on the analysis of paired samples t-test and paired samples statistics. Meanwhile, the result of questionnaire on the students' perception and attitude after having experience on using scaffolding instruction was explained later on

\section{A. The Result of Pre-test and Post-test}

The result of pre-test and post-test could be seen from Table 2 explicating the analysis of paired samples t-test and paired samples statistics. It showed the descriptive and pairedsample t-test results of the participants' mean score before and after the treatment.

TABLE II. Paired SAmples Statistics and T-Tests of Pre-Test AND POST-TEST

\begin{tabular}{|c|c|c|c|c|c|c|c|}
\hline & & Mean & $\mathbf{N}$ & $\begin{array}{c}\text { Std. } \\
\text { Deviatio } \\
n\end{array}$ & $\begin{array}{l}\text { Std. } \\
\text { Error } \\
\text { Mean }\end{array}$ & $\mathbf{t}$ & $\begin{array}{c}\text { Sig. (2- } \\
\text { tailed) } \\
*\end{array}$ \\
\hline $\begin{array}{l}\text { Pair } \\
1\end{array}$ & $\begin{array}{l}\text { Pre } \\
\text { Test }\end{array}$ & 52.00 & 32 & 9.89 & 1.75 & -28.87 & .000 \\
\hline & $\begin{array}{l}\text { Post } \\
\text { Test }\end{array}$ & 85.00 & 32 & 6.03 & 1.07 & & \\
\hline
\end{tabular}

Table 2 showed that there was significant difference between before and after the treatment of Scaffolding instruction because the probability (p) due to sampling error was less than alpha (a) set by the researcher $(.000<.05)$. Therefore, the null hypothesis stated that "The use of scaffolding instruction strategy does not enhance the junior high school students' reading comprehension "was rejected. On average, the students as participants experienced significantly greater score on post-test result using scaffolding instruction $(\mathrm{M}=85, \mathrm{SD}=6.03)$ than before using scaffolding instruction $(\mathrm{M}=52, \mathrm{SD}=9.89), \mathrm{t}(31)=-28.87, \mathrm{p}<.05$.

The distance between pre-test and post on using scaffolding instruction as seen on Table 2 was $33(85-52=33)$. So the students' reading comprehension score was 33 better after having treatment on scaffolding instruction than before the treatment. It indicated that their reading comprehension increased along the way of their improvement to identify the generic structure and language feature, and enlargement of their vocabulary.

Furthermore, the implementation of the teaching and learning without using scaffolding showed that the value of student learning outcomes obtained was: lowest value 40, highest value 76 , and average value 52 . As a comparison, the teaching and learning by using scaffolding showed that the value of students' learning outcomes obtained was lowest value 72 , highest value 92 , and average value 85 . It can be concluded that the implementation of the teaching and learning using scaffolding was very significant to increase the students' reading comprehension as seen in Figure 1, the student's 
learning outcome before and after using scaffolding instruction as follows.

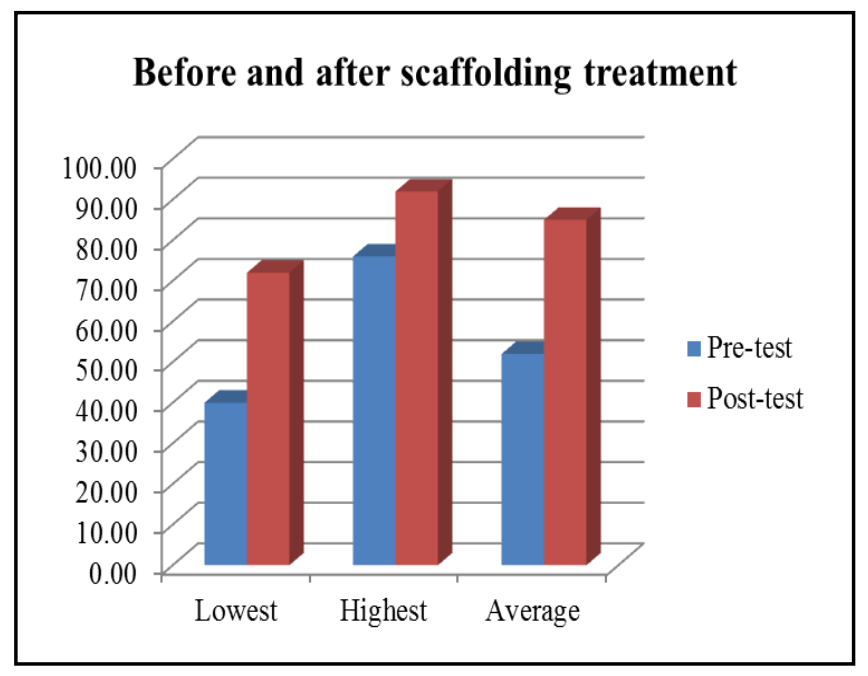

Fig. 1. The student's learning outcome before and after using scaffolding instruction.

\section{B. The Result of Questionnaire}

Questionnaire was distributed to the participants after the implementation of scaffolding instruction. It contained twelve statements requiring the participants answer by choosing SD (Strongly Disagree), D (Disagree), N (Neutral), A (Agree), and SA (Strongly Agree) as seen in TABLE III as follows.

TABLE III. The Students' Perception ANd AtTITUde ON THE Use SCAFFOLDING INSTRUCTION

\begin{tabular}{|l|l|l|l|l|l|l|}
\hline No & \multicolumn{1}{|c|}{ Statements } & SD & D & N & A & SA \\
\cline { 3 - 7 } & & \multicolumn{1}{|l}{ I } & 2 & 3 & 4 & 5 \\
\hline 1 & I like reading text in English & 2 & 2 & 7 & 11 & 10 \\
\hline 2 & $\begin{array}{l}\text { I like reading the text when it is } \\
\text { from my interest }\end{array}$ & 3 & 1 & 1 & 12 & 15 \\
\hline 3 & I like reading illustrative text & 1 & 1 & 2 & 15 & 13 \\
\hline 4 & $\begin{array}{l}\text { I feel motivated by reading in } \\
\text { class }\end{array}$ & 0 & 0 & 1 & 15 & 16 \\
\hline 5 & $\begin{array}{l}\text { I need to learn more words to } \\
\text { comprehend a text better }\end{array}$ & 0 & 2 & 2 & 10 & 18 \\
\hline 6 & $\begin{array}{l}\text { I understand better text when I use } \\
\text { graphic organizer }\end{array}$ & 1 & 0 & 2 & 17 & 12 \\
\hline 7 & $\begin{array}{l}\text { I often work in pair to do reading } \\
\text { comprehension activity in the } \\
\text { classroom }\end{array}$ & 0 & 1 & 1 & 18 & 12 \\
\hline 8 & $\begin{array}{l}\text { My teacher encourages me to find } \\
\text { main ideas and the details }\end{array}$ & 2 & 2 & 2 & 9 & 17 \\
\hline 9 & $\begin{array}{l}\text { My teacher promotes questions } \\
\text { before starting reading activities }\end{array}$ & 0 & 2 & 2 & 16 & 12 \\
\hline 10 & $\begin{array}{l}\text { My teacher uses reading guide for } \\
\text { reading exercise }\end{array}$ & 0 & 0 & 3 & 18 & 11 \\
\hline 11 & $\begin{array}{l}\text { At the end of the reading } \\
\text { activities, my teacher asked me to } \\
\text { relate it with my experience }\end{array}$ & 1 & 2 & 1 & 20 & 8 \\
\hline 12 & $\begin{array}{l}\text { Using scaffolding make me feel } \\
\text { enjoy the process in learning }\end{array}$ & 2 & 0 & 1 & 13 & 16 \\
\hline Total Response & 12 & 13 & 25 & 174 & 160 \\
\hline
\end{tabular}

In general, junior high school students have positive attitude on using scaffolding instruction showed from the portrait of their response from TABLE III. They felt they got encouragement from the teacher to find main ideas and the details when the instruction was done and therefore they agree and strongly agree about this encouragement $(10+17)$. The students enjoyed learning well, they looked very exciting and interested in the teaching learning process $(13+16)$. Many of them said that it was very easy to identify the generic structure and language features especially when they were using graphic organizer by stating agree and strongly agree $(17+12)$. The students felt that scaffolding was very helpful to understand the text although many of them still considered that to comprehend the text in several parts is still difficult because of their vocabulary limitation and therefore they angreed and strongly agreed $(10+18)$ to learn more word to understand reading better. In short, the student's response in general could be summarized from Figure 2 as follows.

\section{Total response of students' perception using scaffolding instruction}

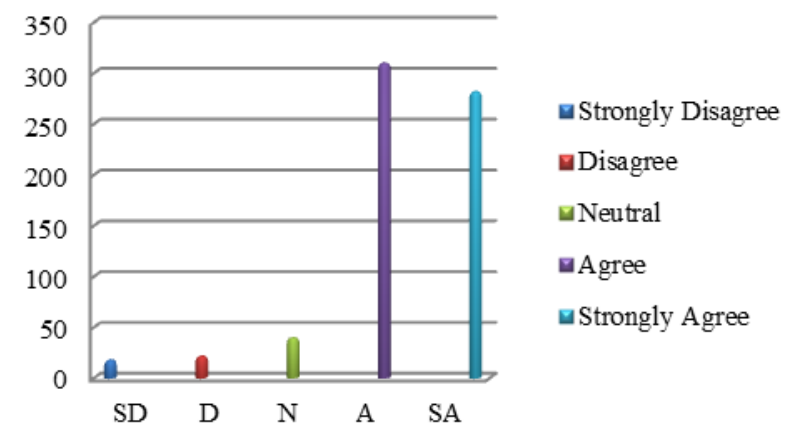

Fig. 2. Total response of students' perception using scaffolding instruction.

\section{Discussion}

The objective of the present study is to investigate the effect of scaffolding instruction on reading comprehension for junior high school. It shows that the scaffolding instruction strategy can enhance students reading comprehension skills by looking at the results of the students' pre-test in comparison to their post-test score. The significant increase in classroom activity certainly has an impact on students' scores in reading. In addition, the result of questionnaire shows that the cooperative and conducive classroom atmosphere for learning makes students' motivation in reading better many times $(15+$ 16). These results are consistent with the results of research conducted by Safadi and Rababah [6] stating that scaffolding instruction provide significant results on improving students' reading skills. It is also in line with Salem [7] arguing that the use of scaffolding strategy in the classroom teaching could improve the students' reading skills especially when teachers are getting more aware of the benefit to use scaffolding by communicating with learners as seen in the present study from the encouragement, promoting question, using reading guide, and relating with learners' experience (see questionnaire item numbers $8,9,10$, and 11). 
The present study reveals that scaffolding instruction provide reading comprehension enhancement on the basis of pre-test and post-test score result. Besides, the active classroom atmosphere that avoid boredom makes learners enjoyed the teaching-learning process and the genre of the text were very short story. In line with the present study, [8] on scaffolding students' expository text reading revealed that the highmultimodal scaffolding text significantly boosted science reading comprehension for whose comprehension were low. However, a comparison of posttest comprehension between conditions showed no significant differences till learners use hint to understand the history text and they finally performed significantly better on the posttest afterward. It indicates that learners need hints to understand history text better [9]. Ter Beek et al's study found no differences between conditions regarding students' self-regulated learning or motivation, but students' awareness of problem-solving reading strategies significantly increased in the experimental condition. Difference use of text type, Sholeh et al. [10] 's investigation for Scaffolded Voluntary Reading (SVR) leads to the improvement of reading comprehension and self-selected reading, independent reading, and student-centered learning since the extensive reading text materials used by Sholeh et all are commonly based upon learners' interest which is in accordance with the concept of self-regulated learning practiced in SVR.

The students perception on the use of scaffolding instruction shows positive attitude which is relevant to the study of Dewi and Muzammil [11] focusing on one of the component on scaffolding strategy, using direct metacognitive strategy, make learners better readers and when teachers are getting more aware of the benefit to use scaffolding by communicating with learners [7]. Besides, learners in the present study enjoyed learning well, they looked very exciting and interested in the teaching learning process. In this case, it is quite relevant to the findings of Sholeh et al. [10] toward responses to the questionnaires on SVR, they enjoyed reading, liked to have discussion, and liked to share what they have read and therefore the students increased their reading comprehension as a result of the SVR.

\section{CONCLUSION}

Based on the research results, the present study could be concluded that using scaffolding instruction strategy benefits learners to develop their reading comprehension skill. It could be seen from their improvement of reading comprehension score and from their positive attitude and perception on using this strategy. Using scaffolding instruction could not only invite students' participation but make them think more critically, read the text well, and enjoy the teaching-learning process as well. Therefore, teachers are recommended to utilize scaffolding instruction to boost learners' reading comprehension and to make the teaching-learning process more vivid. Future researchers should notice the text types and students' levels before conducting the study.

\section{ACKNOWLEDGMENT}

The authors thank Pascasarjana and P3U Universitas PGRI Kanjuruhan Malang supporting this article publication without which is not going to be in the present.

\section{REFERENCES}

[1] D. Wood, J.S. Bruner, and G. Ross, "the Role of Tutoring in Problem Solving,” J. Child Psychol. Psychiatry, vol. 17, no. 2, pp. 89-100, 1976.

[2] B.J. Reiser, "Scaffolding Complex Learning: The Mechanisms of Structuring and Problematizing Student Work," Scaffolding A Spec. issue J. Learn. Sci., vol. 13, no. 3, pp. 273-304, 2004.

[3] A. Walqui, "Scaffolding instruction for english language learners: A conceptual framework," Int. J. Biling. Educ. Biling., vol. 9, no. 2, pp. 159-180, 2006.

[4] D. Suherdi, "Scaffolding In Junior High School (SMP) English Teaching-Learning Processes.," in A Paper presented in the International Conference on Applied Linguistics, pp. 11-12, 2008

[5] D. Reynolds, "Interactional Scaffolding for Reading Comprehension," Lit. Res. Theory, Method, Pract., vol. 66, no. 1, pp. 135-156, 2017.

[6] E. Safadi and G. Rababah, "the Effect of Scaffolding Instruction on Reading Comprehension Skills,” Int. J. Lang. Stud., vol. 6, no. 2, pp. 138, 2012.

[7] A.A.M.S. Salem, "Scaffolding Reading Comprehension Skills," English Lang. Teach., vol. 10, no. 1, pp. 97-111, 2017.

[8] A. Meneses, J.P. Escobar, and S. Véliz, "The effects of multimodal text on science reading comprehension in Chilean fifth-graders: text scaffolding and comprehension skills," Int. J. Sci. Educ., vol. 40, no. 18, pp. 2226-2244, 2018.

[9] M. ter Beek, M.C. Opdenakker, A.W. Spijkerboer, L. Brummer, H.W. Ozinga, and J.W. Strijbos, "Scaffolding expository history text reading: Effects on adolescents' comprehension, self-regulation, and motivation," Learn. Individ. Differ., vol. 74, no. December 2018, p. 101749, 2019

[10] A. Sholeh, P. Setyosari, B. Y. Cahyono, and Sulthoni, "Effects of scaffolded voluntary reading on efl students' reading comprehension," Int. J. Instr., vol. 12, no. 4, pp. 297-312, 2019

[11] S.L. Dewi and L. Muzammil, "Students' attitudes to metacognitive strategies for learning how to read,” Int. J. Lang. Stud., vol. 14, no. 4, pp. 51-62, 2020.

[12] C. Symons, "Instructional practices for scaffolding emergent bilinguals' comprehension of informational science texts," Pedagogies, vol. 00, no. 00, pp. 1-19, 2020. 